\title{
Adil Davranışlar Gösterme Ölçeği (ADGÖ)
}

\section{Dr.Yasemin GÜLEÇ*}

Atıf / @- Güleç, Y. (2017). Adil Davranışlar Gösterme Ölçeği (ADGÖ), Çukurova Üniversitesi Ilahiyat Fakültesi Dergisi, 17 (1), 299-315.

Öz- Bu çalışmanın amacı "Adil Davranışlar Gösterme Ölçeği" nin geçerlik ve güvenirlik çalışmasının sonuçlarını ortaya koymaktır. Ölçek İslam ahlakına göre adalet erdeminin ilkelerinden yararlanılarak hazırlanmıştır. Ölçeğin hazırlık aşamasında, uzman görüşlerinden sonra,70 maddeden 26 madde çıkarılmış madde sayısı 44'e indirilmiştir. Pilot uygulama yedi farklı fakülte ve bölümden rastlantısal olarak seçilen 256 üniversite öğrencisi üzerinde yapılmıştır. Faktör analizi sonucunda, dağınık ve düşük yük değerlerinden dolayı olumsuz ifade içeren 2 madde, ayrıca denekler tarafından tam olarak anlaşılmadığı düşünülen 3 madde çıkarılmıştır. Daha sonra bazı maddelerin ifadeleri değiştirilip, yeni sorular da eklenerek, 40 maddelik bir form oluşturulmuştur. 40 maddeden oluşan yeni anket formu, 9 farklı fakülte ve bölümlerden 1. ve 4. sınıfta öğrenim gören 919 kişilik gruba uygulanmıştır. Faktör analizi sonucunda bazı maddeler dağınık ve düşük yük değerlerinden dolayı ölçekten çıkarılmış, toplam varyansın \% 61,302 'sini açıklayan 32 madde ve altı boyut ortaya çıkmıştır. Varimax faktör döndürme işleminden sonra, teorik bilgiler çerçevesinde, madde yüklerinin de birbirine yakınlığı göz önüne alınarak, 32 maddeden oluşan 5 boyutlu ("inanç-ibadet", "farkındalık" "emanet-doğruluk", "önyargıdan uzak olma", "israftan kaçınma") bir ölçek elde edilmiştir. Ölçeğin yapı geçerliliğini test etmek amacıyla yapılan faktör analizi ve güvenilirliğini test etmek için yapılan iç-tutarlıık analizi sonuçları, "Adil Davranışlar Gösterme Ölçeği (ADGÖ)" nin geçerli, güvenilir ve istatistikî açıdan araştırmaya uygun olduğunu göstermektedir.

Anahtar sözcükler- Dini ahlak, adalet erdemi, adil olma, adil davranışlar gösterme ölçeği

\section{$\S \S \S$}

Makalenin gelişi 06.12.2016; Yayına kabul tarihi: 19.06.2017

* Karlsruhe Eğitim Ateşeliği Felsefe ve Din Bilimleri-Din Eğitimi, Pforzheim/Karlsruhe Almanya, e-posta: yasemingulec8@gmail.com 


\section{Giriş}

İslam filozof ve ahlakçıları ahlaki değer tasniflerine,$^{1}$ adalet erdeminin kapsamına giren erdemlere yer vermişlerdir. ${ }^{2}$ Ancak günümüzde uygulanan ve yaygın hale gelen, ahlakın testlerle ölçülmesi gibi bir çaba içersinde olmamışlardır. Batı literatüründe psikolojide değer testleri ilk defa Spanger (Spanger, 2001) tarafından kullanımıştır. Spanger'dan ilham alarak yapılan "Study of Values" adlı geniş bir çalışmada (Allport, Vernon, \& Linzey, A Study Of Values, 1960) değerler altı grup ${ }^{3}$ halinde ele alınmıştır. Daha sonraki çalışmalarda daha sistemli ve analitik değer kategorileri geliştirildiği görülmektedir (Schwartz, 1992) (Rokeach, 1973).

Ahlaki değerler üzerinde yapılan çalışmalar, ahlaki değerleri birçok başlık altında toplamaktadır (Lickona, 1991) (Deroche \& William, 2001) Lickona ahlaki değerleri; "dürüstlük, saygı, sorumluluk, sempati, iç disiplin, kararlılık, yardımseverlik, işbirliği ve cesaret" olarak sınıflandırmaktadır. Deroche ve William ise; "dürüstlük, performans değerlerine saygı (iş eğitimi ve disiplin), farlılıklara saygı, takım üyesi olarak diğerleriyle çalışabilme, yaptığı davranışın sorumluluğunu üstlenme, diğerlerine ve otoriteye saygı, kişisel hayat ve aile hayatına adanmışlık, vatandaşı olduğu ülke ile gurur duymak, kendine saygı, sürekli gelişme için hedef ve hayat hakkında heyecan" olarak sınıflandırmaktadır.

Ahlak psikolojisi sahasında, ahlaki gelişmeyi merhaleler halinde ele alan, kaynağı Piaget'e dayanan, Kolberg tarafından geliştirilen ve uygulanan çalışmalar yapılmıştır. Türkiye'de Güngör'ün (Güngör, 1993) çalışması ahlakın

1 Dört Erdem Teorisi: i. Arzu gücü (el-kuvvet'üş-şeheviyye)'nün itidalinden; iffet. ii. Öfke gücünün itidalinden; şecaat. iii. Akıl gücünün itidalinden; hikmet. iv. Üç erdemin (iffet, şecaat, hikmet) birlikte bulunmasıyla adalet gerçekleşir. İslam filozof ve ahlakçılarının, Kınalızade'ye kadar, dört erdem teorisini çok küçük farklarla tekrar ettikleri görülmektedir.

2 İbn Miskeveyh, adalet faziletinin kapsamına giren erdemleri yirmiye ayırmıştır: 1Sadâkat 2-Ülfet3-Vefa 4-Şefkat 5-Merhamet 6-Mükâfat 7-Güzel işbirliği 8-Güzel hüküm 9-Hürmet 10- Teslim 11-Tevekkül 12-Ibadet 13-Kini terk etmek 14Mükafâtu'l-hayr bi'ş-şer (kötülüğe iyilikle karşılık vermek) 15-İsti'malu'l-lutuf (lutüfkar olmak) 16-Mürüvvet 17-Birinin kötülüğünü anlatmama 18-Birinin iyiliğini anlatma 19-Terkü'I-muâdat (düşmanlık etmemek) 20-Allah'ın adını yemin olarak kullanmaktan kaçınma olarak yirmiye ayırmıştır. Nasreddin Tusi bu erdemleri on ikiye indirmiştir: 1-Sadakat 2-Ülfet 3-Vefa 4-Şefkat 5-Merhamet 6-Mükâfat 7-Güzel işbirliği 8-Güzel hüküm 9-Hürmet 10-Teslim 11-Tevekkül 12-İbadet. Kınalızade ve Gülşeni de bu konuda Tusi'yi takip etmişlerdir.

3 Estetik, teorik, iktisadi, siyasi, sosyal ve dini değerler. 
testle ölçülmesi alanında önemli bir çalışmadır. ${ }^{4}$ Son yıllarda, bu alanda yapılan çalışmalar artarak devam etmektedir. Üniversite, lise ${ }^{5}$ ve ilköğretim ${ }^{6}$ öğrencileri düzeyinde hazırlanan ahlaki değer ölçekleri bulunmaktadır. Üniversite öğrencileri seviyesinde hazırlanan Ahlaki Değerler Ölçeği; saygı/dürüstlük, kendini kontrol/disiplin, sorumluluk, kararlılık, işbirliği, empati kibarlık/naziklik, vatanseverlik/vatandaşlık, tolerans/farklılık olarak dokuz (9) alt boyuttan oluşmaktadır (Cafoğlu \& Akar, 2004).

Araştırmacı tarafından geliştirilen bu ölçek, Türk toplumunun diniahlaki yapısını içeriden kavrama çabasında olması, kuramsal temelinin özgünlüğü açısından önem arz etmektedir. Ahlak eğitim ve öğretimi ile ilgili çaIışmalar incelendiğinde, çoğunlukla benzer teorik temellendirmelerden hareket edildiği, alan araştırmalarında kullanılan ölçeklerin teorik temellerinin özgün bir şekilde verilemediği, çoğu zaman diğer kültürlerden ölçek uyarlama çalışmalarına başvurulduğu görülmektedir. Bu sebeple ahlaki erdemlerin, ana ve alt erdemler olarak sade ve anlaşılır bir şekilde, dini-ahlaki yapıya uygun etimolojik tahlillerinin yapılması, bu doğrultuda alan araştırmalarıyla desteklenmesi önem arz etmektedir.

Bu ölçeğin geçerlik ve güvenirlik çalışmaları (17-26) yaş grubundaki üniversite öğrencileri üzerinde yapılmıştır. Çalışmada öğrencilerin adil davranışlarda bulunma eğilimleri, dört ana boyuttan hareketle, beş boyutta ele alınmakta, öğrencilerin davranışları 32 madde ile ölçülmektedir:

i. Allah-insan; inanç-ibadet (10 madde).

ii. İnsan- kendisi; farkındalık (7 madde).

iii. İnsan-toplum; emanet-doğruluk (6 madde), önyargıdan uzak olma (4 madde).

iv. İnsan-tabiat; israftan kaçınma (5 madde).

4 Güngör bu çalışmasında, Spanger ve Allport, Vernon ve Lindzey 'in klasik değer tercihleri sırasına (estetik, teorik, iktisadi, siyasi, sosyal ve dini değerler) ahlaki değerleri de ekleyerek yeni bir değerler sıralaması ölçeği elde etmiştir.

5 14-17 yaş arası öğrencilere yönelik "İnsani Değerler Ölçeği (IDÖ)" (Dilmaç, 2007), "Toplumsal Değerler Tutum Ölçeği;" "çevrecilik, insan hakları, eşitlik ve sosyal adalet, sosyal bütünlük, sevecenlik, gelenek, sorumluluk, dürüstlük, kontrol" olarak 9 alt boyuttan oluşmaktadır (Gömleksiz, 2004). Şengün ve Kaya tarafından (Şengün, 2008) geliştirilen "Ahlaki Olgunluk Ölçeği" ise 66 maddeden oluşmaktadır. Bu ölçekler beş dereceli likert tipi olarak hazırlanmıştır.

6 İlköğretim yedinci sınıf öğrencilerine yönelik "Adil Olma Ölçeği (AOÖ)" (Katılmış, 2010). 
Ölçekteki maddeler, "hiçbir zaman=1, bazen=2, çoğu zaman=3 her zaman=4 "şeklinde puanlanarak, dörtlü likert ölçeği olarak (Karasar, 2007, s. 139-141) geliştirilmiş̧ir. Her bir boyut için ayrı olmak üzere, aritmetik ortalamalar hesaplanmış ve analizler bu ortalamalara göre yapılmıştır. Puanların artması veya azalması bireylerin "adil olma" erdemine ne kadar sahip olduğu veya olmadığı yönünde fikir vermektedir.

\section{Kuramsal Çerçeve}

Adaleti bir erdem olarak ele almak, daha anlaşılır ve genel bir sınıflamayı gerekli kılmaktadır. Kur'an'da adalet ve zulüm kavramını; "Allah-varlık, Allah-insan, insan-toplum, insan-tabiat ilişkisi" olarak dört ana başlık altında ele almak mümkündür. Dini ahlak açısından adalet erdemi, öncelikle insanın yaratıcısı ile ilişkisinden başlayıp (Alusi, 1997, s. 3/42,16 ; Zemahşeri, 1998, s. 1/608), kendini anlamlandırmasıyla devam eden (İzutsu, Kur'an'da Allah ve Insan, 1975, s. 71-72), topluma doğru uzanan bir süreci ifade etmektedir (Kur'an-ı Kerim, 7/89; 21/112; 24/25; 38/26; 39/69,75; 40/78 ). Bununla birlikte insanın tabi çevreye karşı sorumluluklarını adalet erdemi altında ele almak, ahlaki anlamda insanın, tabii çevre ile ayrılmaz bir bütün (Kur'an-ı Kerim, 2/64, 259; 16/ 65; 29/63; 30/19, 24; 35/ 9; 36/33; 57/17) olduğu düşüncesinden kaynaklanmaktadır.

Erdemleri kesin çizgilerle birbirinden ayırmanın zor olduğu, hiçbir zaman göz ardı edilmemelidir. Ancak erdemlerin mahiyetinin daha iyi anlaşılmasına ve uygulanmasına katkı sağlamak için, genel bir tanımlama ve sınıflama yapılması faydalı olabilir. Tabandan başlayan ve zirveye doğru ilerleyen faziletler çizgisinde, adalet erdeminin tabanda (başlangıç) bulunması makul görünmektedir. ${ }^{7}$ Diğer ahlaki faziletlere ulaşabilmek için, öncelikle herkesin erdem açısından asgari nitelikleri bulundurması gerekmektedir. Adalet, kişinin gereken kadar verip, hakkını alması, iyilik ise, gerekenden daha fazla verip, hakkından daha azını almasıdır (İsfehani, 2002, s. 552). Adaletin üstünde iyilik varsa, iyiliğin üstünde de sevgiye dair erdemlerin olması beklenir. Böylece erdem yoluna girmenin ilk basamağı, adil olma çabasıyla başlamış olur. Bu sınıflandırmadan, adalet erdeminin, iyilik ve sevgiye dair erdemlere kıyasla daha önemsiz olduğu çıkarılamaz. Adil olmanın ne anlama geldiğini bilmek, diğer erdemlerin mahiyetinin daha iyi anlaşılmasına ve uygulanmasına katkı saylayacaktır (Güleç, 2014, s. 29).

7 Bkz. Ek I: Şekil 1. Ahlaki Değerlerin Sınıflandırılması 
Kur'an'da adalet ve zulüm kavramının anlamları (İzutsu, 1991, s. 222 ; Ece, 2000 , s. 27 ; Alusi, 1997, s. 155) bazı İslam filozof ve ahlakçılarının adalet erdemi ile ilgili görüşleri (Rifat, tsz., s. 21; Sina, eş-Şifa, el-İlahiyat, 1960, s. 441; Farabi, 1983, s. 63-64; Miskeveyh, Risâle fî Mâhiyeti'l-Adl, 1964, s. 1819; Kınalızade, tsz, s. 124) birlikte değerlendirildiğinde, adalet erdeminin, din ve ahlak eğitimine yansımaları; "sorumluluk", "hakkaniyet", "denge " prensibi olarak ortaya çıkmaktadır. Adaletin mahiyetini oluşturan, sorumluluk, hakkaniyet ve denge prensiplerine riayet etmek, o davranışın "adil" vasfını almasının öncelikli şartlarıdır. Bununla birlikte, "adil olma" hem bu prensiplerden ayrılmamayı, hem de bunların "istikrarı" bir şekilde yapılmasını gerektirmektedir. Aynı zamanda adalet erdemi, adil olan davranışların başkalarına yayılıp paylaşılmasıyla olgunlaşır (Güleç, 2014, s. 31-58).

Adalet, ideal bir toplum için ideal bir durum (Platon, 1975, s. 435/ a-b) olmakla birlikte, öncelikle bireyde başlaması gereken bir erdemdir. İnsana ait kişisel ve toplumsal bir olgu, paylaşımı ve sorumluluk duygusunu harekete geçiren bir duygudur. Ancak insan bu sorumluluk duygusuna aykırı hareket edebilir. Bu sebeple insana sorumluluklarının daima hatırlatılması gerekmektedir. Fıtrattaki doğruya yönelme ve adaleti gerçekleştirme yönündeki eğiliminden (Kindi, 1994, s. 71-72; Sina, eş-Şifa, el-İlahiyat, 1960, s. 429-430; Miskeveyh, Ahlakı Olgunlaştırma, 1983, s. 103) kasıtlı olarak uzaklaştıran bir dini ve ahlaki eğitim verilmedikçe, her insan temel ahlaki erdemlere karşı meyilli bulunmaktadır.

İnsandaki önemli duygulardan biri olan bencillik, hakkaniyet ilkesinin ihlal edilmesine, insanın adaletten ayrılıp zulme yönelmesine sebep olan en önemli etkenlerden biridir (Kur'an-ı Kerim, 2/145; 4/153; 30/29; 38/26). İnsanın bir ifrattan diğerine sıçraması, bazı temel ahlaki gerginlikleri açığa çıkarmaktadır. Insan davranışlarının istikrarlı ve verimli olması isteniyorsa, eğitimin faaliyet göstermesi gereken yer, bu ahlaki gerginlikler alanıdır (Fazlurrahman, 1998, s. 63).

Adil olmanın insanın tek bir tarafıyla ilgili olduğunu söylemek mümkün değildir. Gerçekte adalet, bir bütün olarak, nasıl insan olunması gerektiği ile yakından ilgilidir. Bu erdem, bir kişiye, "başkalarının haklarına saygı göstermeyi emrettiği gibi, başkalarının da o kişinin haklarına saygı göstermelerini" salık verir.

Adalet, ister toplumsal ister bireysel olsun, bir uyum ve denge halidir. Adalette ruhun iç durumu, iç eylemlerindeki düzen ve ödevin yerine getirilmesi söz konusudur. Böylece ruhun bütün bölümleri kendine düşen işi iyi yaparsa, 
hepsi bir uyum içerisinde bulunursa, ruhun erdemi de doğru bir nitelik kazanır ve bölümleri arasında doğru bir bağlantı kurar (Platon, 1975, s. 443/d-e ; Sina, Tis'u Resail fi'l-Hikme ve't Tabiiyyat, 1298, s. 102-103). Akıl ve duygu ayrımı yaparak, duyguları birer zayıflık olarak görüp, onların eğitilmez olduğu düşünüldüğünde ${ }^{8}$ işlenip geliştirilmesi mümkün olmayacaktır. Gerçekte zulme sebep olan davranış, bilgisizlikten çok, duyguların dengede olmamasından kaynaklanmaktadır. Bu sebeple İslam ahlakı, zulüm karakterini eğitmede, duygu eğitimine ağırlık verilmesini salık vermektedir.

Bazı bireylerin ahlaki anlamda en yüksek anlayış ve duyarlılığa ulaşabilmesi mümkün olabilir. Ancak hiçbir bireyde ahlaki sorgulamalar bitmez. İnsan, hayat boyu fazilette hep daha yükseği aramaya eğilimlidir. Bu arayışın, insanın yaratılışındaki "adalet duygusundan" kaynaklandığını söylemek mümkündür.

\section{Yöntem}

\section{Araştırma Modeli}

Araştırma bir ölçek geliştirme çalışması niteliğindedir. Veriler, olasıllğa dayalı örnekleme yöntemlerinden biri olan basit tesadüfî örnekleme (Altınışık, Coşkun, Bayraktaroğlu, \& Yıldırım, 2010, s. 138) yöntemiyle, anket tekniğinden faydalanılarak toplanmıştır.

\section{Evren ve Örneklem}

Ölçeğin geçerlik ve güvenirlik çalışmaları için pilot uygulama, 20122013 eğitim-öğretim yılı güz döneminde, İstanbul'da öğrenimlerine devam eden; Hukuk, Tıp, İlahiyat, Eğitim, Felsefe, İktisat, Mühendislik fakülte ve bölümlerinde okuyan 256 üniversite öğrencisi üzerinde yapılmıştır.

İkinci uygulama, 2012-2013 öğretim yılı bahar yarıyılı itibariyle İstanbul Üniversitesi'nin dokuz farklı fakülte ve bölümlerinde öğrenimlerine devam etmekte olan 1. ve 4. sınıflardan, 17-26 yaşları arasındaki, 919 üniversite öğrencisinden oluşturulmuştur. Araştırmaya katılanların \% 55,9'u (s=514) erkek, \% 44,1'i (s= 405) kadındır. Örneklemin \% 28,4'ü (s=257) 17-19 yaş aralığında, \% 71,6'sı (s=648 ) 20-26 yaş aralığındadır.

8 Aristo, ev yapa yapa mimar, gitar çala çala gitarcı olunduğunu, bunun gibi adil şeyler yapa yapa adil insan, ölçülü davrana davrana ölçülü insan, yiğitçe davrana davrana yiğit insanlar olunabileceğini düşünmektedir (Aristo, 2007, s. 29-30) 


\section{Adil Davranışlar Gösterme Ölçeği'nin (ADGÖ) Maddelerinin Geliştirilmesi}

Öncelikle Kur'an' da adalet erdemi, bazı filozof ve ahlakçıların adalet teorileri incelendikten sonra, adalet erdemi ile ilgili bilgileri bir bütün olarak ele alarak, Türk toplumunun sosyal, kültürel, dini, ahlaki yapısı düşünülerek sorular hazırlanmıştır. Adalet erdeminin ahlaki anlamda, erdemlilik aşamasında bir başlangıç olduğu düşüncesinden hareketle, adil olmakla ilgili olabilecek düşünce, duygu ve tutumlar asgari düzeyde tutulmuş, aşırı idealize edilmiş, anlaşılması zor ve uzun cümlelere yer verilmemiştir. İnsanın yaratıcısına karşı en önemli görevleri, duygu, düşünce ve davranışlarında kendisini ne kadar tanıdığı, diğer insanlarla olumlu ilişkiler kurabilme, ayrıca insanın kendisiyle bir bütün oluşturan tabiatın farkına varması ile ilgili ifadelerin bulunduğu, 70 maddelik bir havuz oluşturulmuştur.

Madde havuzunu oluşturan ifadelerin, üniversite öğrencilerinin adil olma düzeylerini ölçebilirliği konusunda, kapsam geçerliklerini belirlemek amacıyla uzman görüşüne başvurulmuştur (Büyüköztürk, 2011, s. 168). Uzman görüşlerinden sonra, 26 madde havuzdan çıkarılarak, 44 maddelik deneme formu oluşturulmuştur.

256 kişi üzerinde yapılan pilot çalışma sonucunda, ölçeğin yapı geçerliliğini test etmek için faktör analizi (Büyüköztürk, 2011, s. 123-124; Altınışık, Coşkun, Bayraktaroğlu, \& Yıldırım, 2010, s. 121) yapılmıştır. KaiserMayer-Olkin (KMO) örneklem yeterlilik testinin (MSA=,81), faktör analizinin dayandığı korelasyonların istatistiksel olarak anlamlılığını gösteren Bartllettküresellik testinin $\left(X^{2}=3,954\right)$ olduğu tespit edilmiştir.

Faktör analizi sonucunda, dağınık ve düşük yük değerlerinden dolayı olumsuz ifade içeren 2 madde, ayrıca denekler tarafından tam olarak anlaşımadığı düşünülen 3 madde çıkarımıştır. Daha sonra bazı maddelerin ifadeleri değiştirilip, yeni sorular eklenerek, 40 maddelik bir form oluşturulmuştur. 


\section{Adil Davranışlar Gösterme Ölçeği'nin (ADGÖ) Geçerlik ve Güvenirlik Çalışmaları}

İlk uygulamadan sonra yapılan değişikliklerle, 40 maddeden oluşan yeni anket formu, 919 kişilik gruba uygulanmıştır. Faktör analizi sonucunda, Bartllett-küresellik testinin $\left(X^{2}=1,585\right)$, Kasiyer Meyer Olkin (KMO) testinin ise (MSA=,91) olduğu tespit edilmiştir.

Her ne kadar MSA değeri, genel olarak faktör analizinin veri seti için uygunluğuna işaret etse de, her bir değişkenin toplam çözüme katkı sağlayıp sağlamadığı veya önerilen çözümde bozucu etkiye sahip olup olmadığını tespit etmek için, anti-image korelasyon matrisi (Altınışık, Coşkun, Bayraktaroğlu, \& Yıldırım, 2010, s. 285) incelenmiştir. Hiç bir maddenin köşegen değerlerinin 0,5 den küçük olmadığı tespit edilmiştir.

Teorik bilgiler ve yapılan ahlaki değer sınıflandırması ${ }^{9}$ doğrultusunda, insanın kendi bedenine karşı sorumluluğunun (sıhhat) ölçülmeye çalışıldığı 5 madde dağınık ve düşük yük değerlerinden dolayı ölçekten çıkarılmıştır. Ayrıca 3 madde $(0,42$ 'nin altında madde yükü olanlar) analiz dışı bırakılmıştır. Analiz sonucunda toplam varyansın \% 61,302 'sini açıklayan altı boyut ortaya çıkmıştır.

Varimax faktör döndürme (Büyüköztürk, 2011, s. 125-126) işleminden sonra, teorik bilgiler çerçevesinde, madde yüklerinin de birbirine yakınlığı göz önüne alınarak, 32 maddeden oluşan 5 boyutlu bir ölçek elde edilmiştir. Ölçeğin (KMO) değeri $(M S A=, 89)$, Bartllett-küresellik testinin $\left(X^{2}=1,480\right)$ olduğu tespit edilmiştir. Ölçeğin güvenilirliğini test etmek için yapılan iç-tutarılık (Altınışık, Coşkun, Bayraktaroğlu, \& Yıldırım, 2010, s. 124) analizi sonrasında ölçeğin genelinin ve alt boyutların iç tutarlılık katsayısını gösteren Cronbach Alpha değerleri şu şekildedir: Ölçek genel $(\alpha=87)$, inanç-ibadet $\left({ }^{\propto-1}=95\right.$; farkındalık $(\propto-2)=75$; emanet-doğruluk $(\propto-3)=78$; önyarıdan uzak olma $\left({ }^{\propto-4}\right)=76$; israfı önleme $\left({ }^{\propto-5}\right)=79$ olarak tespit edilmiştir.

9 Bkz. EK I: Şekil 1. Ahlaki Erdem Sınıflandırması 


\section{Adil Davranışlar Gösterme Ölçeği (ADGÖ)' nin Boyutları}

\subsection{Inanç-İbadet Boyutu}

Tablo- 1: Allah-İnsan: İnanç-İbadet Boyutu Madde Yük ve Toplam Korelasyonu

\begin{tabular}{|l|l|l|l|}
\hline No & İfadeler & Madde Yükü & $\begin{array}{l}\text { Madde Toplam } \\
\text { Korelasyonu }\end{array}$ \\
\hline 3 & $\begin{array}{l}\text { Tüm varlıkların rızkını Allah'ın verdiğine } \\
\text { inanıyorum }\end{array}$ &, 91 &, 90 \\
\hline 4 & Nimetlerin gerçek sahibi Allah'tır. &, 92 &, 89 \\
\hline 2 & $\begin{array}{l}\text { Her şeyi var edenin Allah olduğuna } \\
\text { inanıyorum }\end{array}$ &, 90 &, 87 \\
\hline 1 & Allah'ın varlığına ve birliğine inanıyorum &, 88 &, 86 \\
\hline 6 & $\begin{array}{l}\text { İyiliklerimin Allah tarafından ödüllendiri- } \\
\text { leceğine inanıyorum }\end{array}$ &, 87 &, 87 \\
\hline 9 & İbadetleri yalnızca Allah için yaparım &, 86 &, 86 \\
\hline 7 & $\begin{array}{l}\text { Yapılan kötülüklerin Allah tarafından } \\
\text { cezalandırılacağını düşünürüm }\end{array}$ &, 84 &, 85 \\
\hline 10 & İyilik yaparken Allah rızasını gözetirim &, 82 &, 84 \\
\hline 5 & $\begin{array}{l}\text { Verdiği nimetlerden dolayı Allaha şükre- } \\
\text { derim }\end{array}$ &, 77 &, 79 \\
\hline 8 & $\begin{array}{l}\text { Allah'a karşı farz olan sorumluluklarımı } \\
\text { yerine getirmeye çalışırım }\end{array}$ &, 71 &, 75 \\
\hline
\end{tabular}

İnanç-ibadet boyutu, insanın yaratıcısına karşı adil olması olarak nitelendirilebilecek, duygu, düşünce ve davranışlar içeren tutumlardan oluşmaktadır. Bu boyut toplam 10 maddeden oluşmakta olup, puan ranjı 10-40'dır. Örneklemin bu boyuttan aldığı en düşük puan 10, en yüksek puan 40, ortalama puan $(\overline{\mathrm{x}}=36,44)^{\prime}$ dır (ss.6,13).

\subsection{Farkındalık Boyutu}

Tablo- 2: İnsan- Kendisi: Farkındalık Boyutu Madde Yük ve Toplam Korelasyonu

\begin{tabular}{|l|l|l|l|}
\hline No & İfadeler & $\begin{array}{l}\text { Madde } \\
\text { Yükü }\end{array}$ & $\begin{array}{l}\text { Madde Toplam } \\
\text { Korelasyonu }\end{array}$ \\
\hline 22 & $\begin{array}{l}\text { Yaşadığım sorunların üstesinden gele- } \\
\text { bilmeyi başarırım }\end{array}$ &, 71 &, 70 \\
\hline 21 & Duygularımı kontrol edebilirim &, 66 &, 66 \\
\hline 16 & Zayıf yönlerimi söyleyebilirim &, 61 &, 58 \\
\hline
\end{tabular}




\begin{tabular}{|l|l|l|l|}
23 & $\begin{array}{l}\text { Bir şeyler yapmak için kendi kendimi } \\
\text { harekete geçirebilirim }\end{array}$ &, 60 &, 65 \\
\hline 18 & $\begin{array}{l}\text { Haksızlığa uğradığımda kendimi sorgu- } \\
\text { layabilirim }\end{array}$ &, 59 &, 62 \\
\hline 20 & Yanlış yapınca doğru olana yönelirim &, 58 &, 68 \\
\hline 19 & Elimdeki imkânlarla yetinirim &, 50 &, 58 \\
\hline
\end{tabular}

İnsanın kendisi ile ilişkisinde, kendine karşı adil olması olarak ifade edilebilecek farkındalık yönelimi, kişinin kendini tanıma, duygularını kontrol edebilme, sorunlarını çözebilme, yaptığı hatalardan dönebilme, elindeki imkânları değerlendirebilme gibi duygu, düşünce ve davranışlarını içermektedir. Bu boyut toplam 7 maddeden oluşmakta olup, puan ranjı 7-28'dir. Örneklemin bu boyuttan aldığı en düşük puan 9 , en yüksek puan 28 , ortalama puan $(\overline{\mathrm{x}}=21,05) \operatorname{dir}(\mathrm{ss}=3,07)$.

\subsection{Emanet-doğruluk}

Tablo- 3: İnsan-Toplum: Emanet-Doğruluk Boyutu Madde Yük ve Toplam Korelasyonu

\begin{tabular}{|l|l|l|l|}
\hline No & İfadeler & $\begin{array}{l}\text { Madde } \\
\text { Yükü }\end{array}$ & $\begin{array}{l}\text { Madde Toplam } \\
\text { Korelasyonu }\end{array}$ \\
\hline 25 & Verdiğim sözü yerine getirim &, 76 &, 71 \\
\hline 27 & $\begin{array}{l}\text { Korunmak üzere verilen her şeyi dikkat- } \\
\text { lice korurum }\end{array}$ &, 70 &, 74 \\
\hline 26 & Anne baba hakkını gözetirim &, 65 &, 68 \\
\hline 28 & $\begin{array}{l}\text { Görevli olduğum işi en güzel şekilde } \\
\text { yaparım }\end{array}$ &, 62 &, 68 \\
\hline 24 & Doğruları söyleyebilirim &, 54 &, 65 \\
\hline 29 & Ortak kullanılan kamu mallarını korurum &, 45 &, 67 \\
\hline
\end{tabular}

Emanet- doğruluk boyutu, insanın kendisinden başlayarak, topluma doğru devam eden; sözünde durma, görevli olduğu işi yapma, kamu mallarını koruma, anne-baba başta olma üzere, diğer insanların haklarına saygı gösterme gibi yönelimlerini kapsamaktadır. Bu boyut toplam 6 maddeden oluşmakta olup, puan ranjı 6-24'dür. Örneklemin bu boyuttan aldığı en düşük puan 6 , en yüksek puan 24 , ortalama puan $(\overline{\mathbf{x}}=20,38)$ dir $(s s=2,35)$. 


\section{4. Önyargıdan Uzak Olma Boyutu}

Tablo-4: İnsan-Toplum: Önyargıdan Uzak Olma Boyutu Madde Yük ve Toplam Korelasyonu

\begin{tabular}{|l|l|l|l|}
\hline No & İfadeler & $\begin{array}{l}\text { Madde } \\
\text { Yükü }\end{array}$ & $\begin{array}{l}\text { Madde Toplam } \\
\text { Korelasyonu }\end{array}$ \\
\hline 31 & Farklı inançlara saygı gösteririm &, 82 &, 79 \\
\hline 32 & $\begin{array}{l}\text { Başkalarının düşüncelerine saygı göste- } \\
\text { ririm }\end{array}$ &, 79 &, 83 \\
\hline 30 & Farklı ırklara saygı gösteririm &, 74 &, 75 \\
\hline 33 & $\begin{array}{l}\text { İnsanları tanımadan haklarında olumsuz } \\
\text { düşünmekten kaçınırım }\end{array}$ &, 46 &, 66 \\
\hline
\end{tabular}

Önyargıdan uzak olma boyutu, insanın diğer insanlar ve toplumla ilişkisinde, farklı inanç, düşünce ve ırklara saygı ve hoşgörü gösterme tutumlarını içermektedir. Bu boyut toplam 4 maddeden oluşmakta olup, puan ranjı 416 'dır. Örneklemin bu boyuttan aldığı en düşük puan 4, en yüksek puan 16, ortalama puan $(\overline{\mathbf{x}}=13,83)$ dür $(\mathrm{ss}=1,94)$

\section{5. İsraftan Kaçınma Boyutu}

Tablo- 5: İsraftan Kaçınma Boyutu Madde Yük ve Toplam Korelasyonu

\begin{tabular}{|l|l|l|l|}
\hline No & İfadeler & $\begin{array}{l}\text { Madde } \\
\text { Yükü }\end{array}$ & $\begin{array}{l}\text { Madde Toplam } \\
\text { Korelasyonu }\end{array}$ \\
\hline 36 & $\begin{array}{l}\text { Tabiatın (Doğa) korunması gereken bir } \\
\text { emanet olduğunu düşünürüm }\end{array}$ &, 63 &, 70 \\
\hline 37 & $\begin{array}{l}\text { Hayvanların canı olduğunu düşünerek } \\
\text { onlara zarar vermem }\end{array}$ &, 80 &, 71 \\
\hline 39 & Boşa yanan lambaları söndürürüm &, 79 &, 75 \\
\hline 40 & $\begin{array}{l}\text { Kullanılmayan suyun boşa akmasına izin } \\
\text { vermem }\end{array}$ &, 77 &, 76 \\
\hline 38 & $\begin{array}{l}\text { Doğal güzelliklere zarar vermemeye } \\
\text { dikkat ederim }\end{array}$ &, 72 &, 78 \\
\hline
\end{tabular}

Bu boyut, insanın doğaya karşı öncelikli sorumluluklarını; tabiatı emanet olarak görme, doğal güzelliklere ve hayvanlara zarar vermeme, enerji kaynaklarını gereksiz yere kullanmama gibi yönelimleri içermektedir. Boyut 5 maddeden oluşmakta olup, puan ranjı 5-20'dir. Örneklemin bu boyuttan aldığı 
en düşük puan 8 , en yüksek puan 20 , ortalama puan $(\overline{\mathbf{x}}=17,60)$ dir (ss=2,31).

\section{Sonuç}

Erdemlerin birbiriyle iç içe olduğu, erdemlerin tanımlanırken birbirinden tamamen kopuk olarak tanımlanmasının zor olduğu unutulmamalıdır. Ancak insan davranışlarını anlamlandırmada çok önemli bir değere sahip olan erdemler konusunda araştırma yapan araştırmacıların da bir tanımlamaya gitmek istemeleri doğal kabul edilebilir.

Din bilimleri alanında, din ve değerler eğitim ve öğretimi sahasında yapılacak olan emprik çalışmalar için, bireyi ve toplumu farklı açılardan incelerken, ölçme arçlarına başvurmanın önemi ortadadır. Ancak hazırlanan ölçeklerin ölçülmek istenilen olguyu ölçebilme gücü sürekli tartışılan bir konu olmaya devam etmektedir. Bu anlamda araştırılmak istenen konu hakkında literatür incelemesi, bireysel ve toplumsal algıda konunun algılanma biçimini tespit etmek oldukça önemlidir.

Bu ölçek, Türk toplumunun dini-ahlaki yapısını içeriden kavrama çabasıyla, kuramsal temelinin; Kur'an, bazı filozof ve ahlakçıların, adalet erdemi ile ilgili görüşleri incelendikten sonra, bir ahlaki değerler sınıflandırması yapılarak, erdem ve ilke temelli yaklaşımla maddelerinin oluşturulması bakımından, özgün olma çabasında olan bir ölçektir.

Adil Davranışlar Gösterme (ADGÖ) ölçeğinde, öğrencilerin adil davranışlarda bulunma eğilimleri: "Allah-insan: inanç-ibadet; insan- kendisi: farkındalık; insan-toplum: emanet-doğruluk ve önyargıdan uzak olma; insantabiat: israftan kaçınma" olarak beş boyutta ele alınmakta, öğrencilerin davranışları 32 madde ile ölçülmeye çalışılmaktadır. Ölçekte, kişinin Yaratıcısına karşı en önemli görevleri; duygu, düşünce ve davranışlarında kendisini ne kadar tanıdığı; diğer insanlarla olumlu ilişkiler kurabilme; insanın kendisiyle bir bütün oluşturan tabiatın farkına varması ile ilgili ifadelere yer verilmiştir.

Ölçeğin geçerlik ve güvenirlik çalışmaları 17-26 yaş üniversite öğrencileri üzerinde yapılmıştır. Ölçeğin yapı geçerliliğini test etmek amacıyla yapılan faktör analizi ve güvenilirliğini test etmek için yapılan iç-tutarlılık analizi sonuçları, Adil Davranışlar Gösterme Ölçeği (ADGÖ)'nin geçerli, güvenilir ve istatistikî açıdan araştırmaya uygun olduğunu göstermektedir.

İfade edildiği gibi, ölçeklerin geçerlilik ve güvenirlikleri, ön teorik araştırma, ölçeğin maddelerinin kavramı ölçebilme gücü, araştırmayı yapan araştırmacının deneyimi, araştırmanın zamanı ve araştırmanın yapıldığı örnekle- 
me göre değişebilmektedir. Bu anlamda hazırlanan bu ölçeğin bazı sınırlılıklarının olacağı unutmamalıdır. Ölçekler, farklı araştırmacılar tarafından, farklı örneklem gruplarında uygulanarak, her araştırmada tekrardan geçerlilik ve güvenilirlikleri kontrol edilerek, standart hale getirilmeye çalışılmalıdır.

\section{Kaynakça}

Allport, G. W., Vernon, E., \& Linzey, G. (1960). A Study Of Values. Boston: Houghton-Mifflin.

Altınışık, R., Coşkun, R., Bayraktaroğlu, S., \& Yıldırım, E. (2010). Sosyal Bilimlerde Araştırma Yöntemleri. Sakarya: Sakarya .

Alusi. (1997). Ruhu'l-Meani. Beyrut: Daru'l-Fikr.

Aristo. (2007). Nikomakhos'a Etik. (S. Babür, Çev.) Ankara: Bilgesu.

Büyüköztürk, Ş. (2011). Sosyal Bilimler İçin Veri Analizi El Kitabı. Ankara: Pegem.

Cafoğlu, Z., \& Akar, Ö. (2004). Üniversitelerde Ahlaki Değerlerin Davranışa Yansımasının Oluşturduğu Örgüt İkliminin Algılanması. R. Kaymakcam, S. Kenan, H. Hökelekli, Z. Arslan, \& M. Zengin (Dü) içinde, Değerler ve Eğitimi (s. 773-796). İstanbul: Dem.

Deroche, E. F., \& William, M. M. (2001). Education Hearts And Minds: A Comprehensive Character Education Framework. California: Corwin Press.

Dilmaç, B. (2007). Bir Grup Fen Lisesi Öğrencisine Verilen Insani Değerler Eğitiminin İinsani Değerler Ölçeği İle Sınanması. Konya: Selçuk Üniversitesi Sosyal Bilimler Enstitüsü, Yayımlanmamış Doktora Tezi.

Ece, K. H. (2000). İslam'ın Temel Kavramları. İstanbul: Beyan.

Farabi. (1983). Tahsilü's-Saade. (C. A. Yasin, Dü.) Beyrut: Dârü'l-Endelüs.

Fazlurrahman. ( 1998). Ana Konularıyla Kur’an. (A. Açıkgenç, Çev.) Ankara: Ankara Okulu

Gömleksiz, M. N. (2004). "Lise Öğrencilerinin Toplumsal Değerlere İlişkin Tutumları: Elazığ İli Örneği", Değerler ve Eğitimi. R. Kaymakcan, S. Kenan, H. Hökelekli, M. Zengin, \& Z. Ş. Arslan (Dü.). içinde (s. 727741). İstanbul: Dem.

Güleç, Y. (2014). Adil Davranışlar Göstermede Din Eğitiminin Rolü (İstanbul Üniversitesi Öğrencileri Örneği). Konya: Necmettin Erbakan Üniversitesi Sosyal Bilimler Enstitüsü, Yayımlanmamış Doktora Tezi.

Güngör, E. (1993). Değerler Psikolojisi. Amsterdam: Hollanda Türk Akademisyenler Birliği Vakfı . 
İsfehani. (2002). Müfredat. (S. A. Davudi, Dü.) Beyrut: Dârü'ş-Şamiyye.

İzutsu, T. (1975). Kur’an’da Allah ve Insan. (S. Ateş, Çev.) Ankara: Ankara Üniversitesi.

İzutsu, T. (1991). Kur’an’da Dini ve Ahlaki Kavramlar. (S. Ayaz, Çev.) İstanbul: Pınar.

Karasar, N. (2007). Bilimsel Araştırma Yöntemi. İstanbul: Nobel.

Katılmış, A. (2010). Sosyal Bilgiler Dersindeki Bazı Değişkenlerin Kazandırımasına Yönelik Bir Karakter Eğitimi Programının Geliştirilmesi, İstanbul: Marmara Üniversitesi Eğitim Bilimleri Enstitüsü, Yayımlanmamış Doktora Tezi.

Kınalızade, A. (tsz). Ahlak-ı Alai. (H. Algül, Dü.) İstanbul.

Kindi. (1994). Felsefi Risaleler (Resailu'l-Kindi el-felsefiyye). (M. Kaya, Çev.) İstanbul: İz.

Kur'an-ı Kerim.

Lickona, T. E. (1991). Education For Character: How Schools Can Teach Respect And Resposibility. New York: Bantam Books.

Miskeveyh, İ. (1983). Ahlakı Olgunlaştırma . (A. Şener, \& İ. Kayaoğlu, Çev.) Ankara: Kültür ve Turizm Bakanlığı Yayınları.

Miskeveyh, İ. (1964). Risâle fî Mâhiyeti'l-Adl. (M. Khan, \& E.J.Brill, Dü) Leiden: E.J.Brill.

Platon. (1975). Devlet. (S. Eyyüboğlu, \& M. A. Cimboz, Çev.) İstanbul: Remzi.

Rifat, A. (tsz.). Tasvir-i Ahlak. (H. Algül, Dü.) Tercüman .

Rokeach, M. ( 1973). The Nature of Human Values. New York: Free Press.

Schwartz, S. H. (1992). Universal in the Content and Structure of Values: Theoretical

Advenced And Empirical Test in Countries. L. Berkowitz (Dü.) içinde, Advences in Exprimental Social Psychology (s. 1-65). New York: Academik Press.

Sina, İ. (1298). Tis'u Resail fi'l-Hikme ve't Tabiiyyat. İstanbul: Matbaatü'lCevaib.

Sina, İ. (1960). eş-Şifa, el-ilahiyat. (G.Anavati, \& S.Zaid, Dü) Kahire.

Spanger, E. (2001). Kişilik Tıpleri. (A. Aydoğan, Çev.) İstanbul, İsganbul: İz.

Şengün, M. (2008). Lise Öğrencilerinin Ahlaki Olgunluk Düzeylerinin Bazı Kişisel Değişkenler Açısından Incelenmesi, Samsun: Ondokuz Mayıs Üniversitesi Sosyal Bilimler Enstitüsü, Yayımlanmamış Doktora Tezi.

Zemahşeri. (1998). el-Keşşaf. Riyad: Mektebetü'l-Ubeykan. 


\section{Ek I: Şekiller}

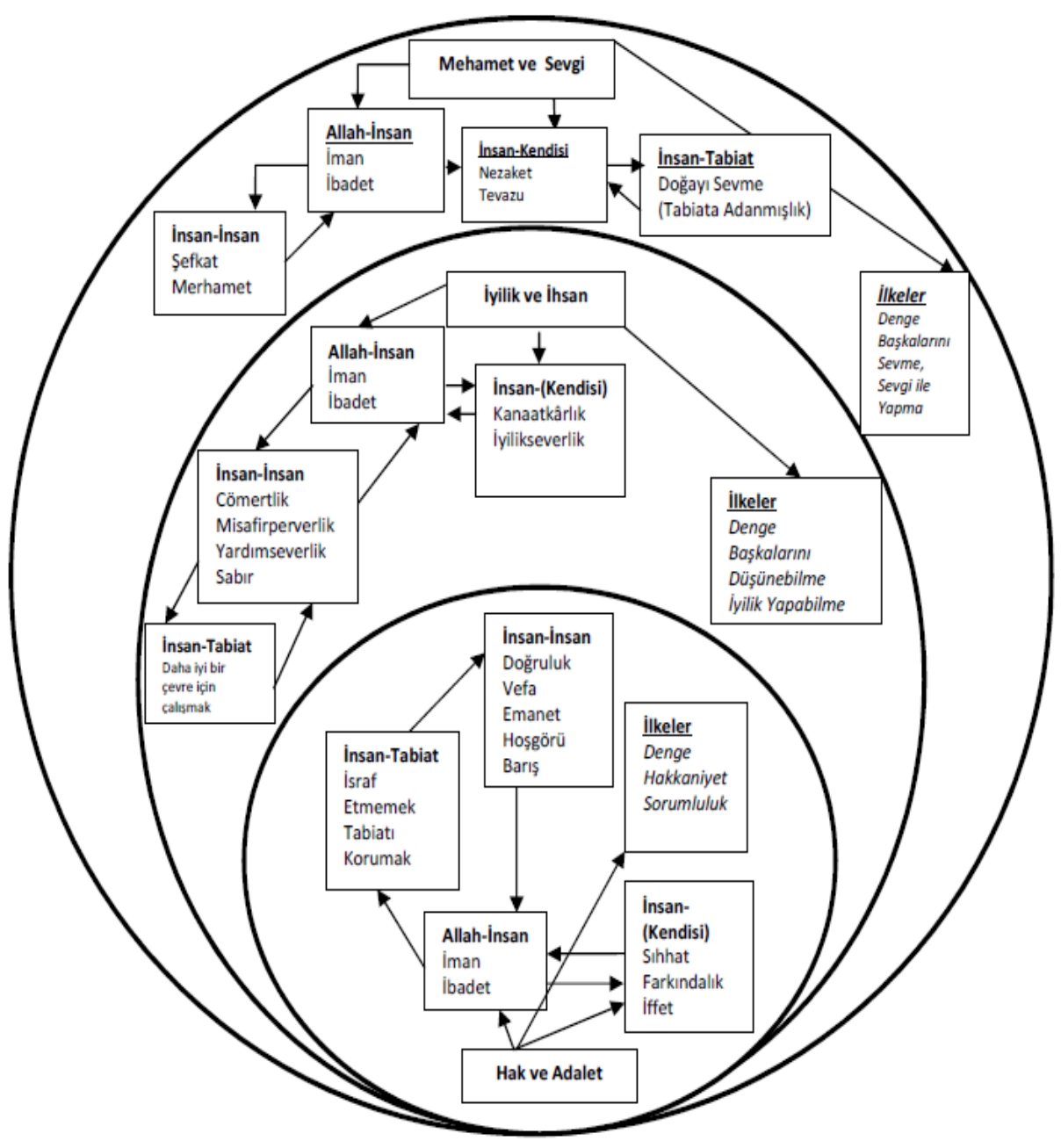

Şekil 1. Ahlaki Değerler Sınıflandırması 


\section{Ek II: Tablolar}

Tablo 1. Adil Davranışlar Gösterme Ölçeği (ADGÖ)

\begin{tabular}{|c|c|c|c|c|}
\hline $\begin{array}{c}\text { Adil Davranışlar Gösterme (ADGÖ) Ölçeği } \\
\text { Aşağıdaki İfadeleri olmak istediğiniz gibi değil olduğunuz gibi } \\
\text { "X"ile belirtiniz. }\end{array}$ & 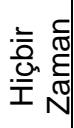 & $\begin{array}{l}\widetilde{\Phi} \\
\mathbb{N} \\
\varnothing \\
\end{array}$ & 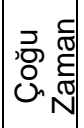 & 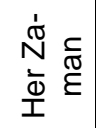 \\
\hline 1) Allah'ın varlığına ve birliğine inanıyorum & & & & \\
\hline 2) Her şeyi var edenin Allah olduğuna inanıyorum & & & & \\
\hline 3) Nimetlerin gerçek sahibi Allah'tır. & & & & \\
\hline 4) Tüm varıkların rızkını Allah'ın verdiğine inanıyorum & & & & \\
\hline 5) Verdiği nimetlerden dolayı Allaha şükrederim & & & & \\
\hline $\begin{array}{l}\text { 6) İyiliklerimin Allah tarafından ödüllendirileceğine inanıyo- } \\
\text { rum }\end{array}$ & & & & \\
\hline $\begin{array}{l}\text { 7) Yapılan kötülüklerin Allah tarafından cezalandırılacağını } \\
\text { düşünürüm }\end{array}$ & & & & \\
\hline $\begin{array}{l}\text { 8) Allah'a karşı farz olan sorumluluklarımı yerine getirmeye } \\
\text { çalışırım }\end{array}$ & & & & \\
\hline 9) İbadetleri yalnızca Allah için yaparım & & & & \\
\hline 10) İyilik yaparken Allah rızasını gözetirim. & & & & \\
\hline 11) Yaşadığım sorunların üstesinden gelebilmeyi başarırım & & & & \\
\hline 12) Duygularımı kontrol edebilirim & & & & \\
\hline 13) Zayıf yönlerimi söyleyebilirim & & & & \\
\hline $\begin{array}{l}\text { 14) Bir şeyler yapmak için kendi kendimi harekete geçirebili- } \\
\text { rim }\end{array}$ & & & & \\
\hline 15) Haksızlığa uğradığımda kendimi sorgulayabilirim & & & & \\
\hline 16) Yanlış yapınca doğru olana yönelirim & & & & \\
\hline 17) Elimdeki imkânlarla yetinirim & & & & \\
\hline 18) Verdiğim sözü yerine getirim & & & & \\
\hline 19) Korunmak üzere verilen her şeyi dikkatlice korurum & & & & \\
\hline 20) Anne baba hakkını gözetirim & & & & \\
\hline 21) Görevli olduğum işi en güzel şekilde yaparım & & & & \\
\hline 22) Doğruları söyleyebilirim & & & & \\
\hline 23) Ortak kullanılan kamu mallarını korurum & & & & \\
\hline 24) Farklı inançlara saygı gösteririm & & & & \\
\hline 25) Başkalarının düşüncelerine saygı gösteririm & & & & \\
\hline 26) Farklı ırklara saygı gösteririm & & & & \\
\hline $\begin{array}{l}\text { 27) İnsanları tanımadan haklarında olumsuz düşünmekten } \\
\text { kaçınırım }\end{array}$ & & & & \\
\hline $\begin{array}{l}\text { 28) Tabiatın (Doğa) korunması gereken bir emanet olduğu- } \\
\text { nu düsünürüm }\end{array}$ & & & & \\
\hline $\begin{array}{l}\text { 29) Hayvanların canı olduğunu düşünerek onlara zarar ver- } \\
\text { mem }\end{array}$ & & & & \\
\hline 30) Boşa yanan lambaları söndürürüm & & & & \\
\hline 31) Kullanılmayan suyun boşa akmasına izin vermem & & & & \\
\hline 32) Doğal güzelliklere zarar vermemeye dikkat ederim & & & & \\
\hline
\end{tabular}




\section{Fair Treatment Scale}

Citation / (C- Güleç, Y. (2017). Fair Treatment Scale, Çukurova University Journal of Faculty of Divinity, 17 (1), 299-315.

Abstract- The aim of this study is to reveal the results of the validity and reliability of "Fair Treatment Scale". The scale was prepared basing on the principles of the virtue of justice in Islamic morality. The first stage of study, having utilized from theoretical background and consulting views of the various experts, it was eliminated 26 elements out of 70 elements that were collected. Number of the elements has been reduced from 70 to 44. Firstly, pilot study has been carried out on the randomly chosen 256 university students in seven different faculties and departments. At the end of the factor analysis, some elements, 2 elements containg negative statements and 3 elements not understood by test subjects have been eliminated, due to statistical scattered and low load. Expressions of other some elements have been altered, in addition to new elements, questionnaire form with 40 elements has been created. Secondly new questionnaire form has been carried out on randomly chosen 919 university students with first and fourth years in nine different faculties and departments. At the end of the factor analysis, some elements have been eliminated, due to statistical scattered and low load, it has been concluded a scale explaining \% 61,302 of the total variance and with 32 elements and six factors. After varimax factor rotation, considering the theoretical background and similar elements in terms of load, it has been obtained a scale consisting of 32 elements and five factors ("faith-worship", "awareness", "trust-righteousness", "being away from prejudice", "avoiding prodigality"). Results of factor analysis for analyzing the construct validity of the scale and for analyzing the reliability of internal consistency have been concluded that the scale was valid, reliable, and suitable for statistical researchs.

Keywords- Religious ethics, virtue of justice, fairness, fair behaviour scale 